Кобзар О. М., к.е.н., с.н.с. Державна установа «Інститут економіки природокористування та сталого розвитку Національної академії наук Украӥни» м. Київ, Украӥна

DOI: https://doi.org/10.30525/978-9934-26-064-3-28

\title{
ЗАСТОСУВАННЯ МЕТОДУ РИНКОВИХ ЦІН ПРИ ОЦІНЮВАННІ ЗМІН У СТАНІ ЕКОСИСТЕМНИХ АКТИВІВ ТЕРИТОРІАЛЬНИХ ГРОМАД ВІД НЕГАТИВНОГО ВПЛИВУ ТВЕРДИХ ПОБУТОВИХ ВІДХОДІВ
}

За даними Міністерства громад та територій України «в Україні за 2019 рік (без урахування даних АР Крим та м. Севастополь) утворилось майже 53 млн. м побутових відходів, або понад 10 млн тонн, які захоронюються на 6 тис. сміттєзвалищ і полігонів загальною площею майже 9 тис. га» [1]. Ефективність реалізації природоохоронних заходів у сфері поводження 3 твердими побутовими відходами залежить від об'єктивності та повноти оцінки стану екосистемних активів територіальних громад та його змін.

Екосистемні активи оцінюють 3 двох позицій [2, с. 78]: поширення/протяжність і стан екосистем; «надання» екосистемних послуг - в поточний момент і в перспективі. Визначення змін у якісних та кількісних характеристиках екосистемних послуг, що надаються екосистемними активами територіальних громад від негативного впливу твердих побутових відходів, як різниці між економічними оцінками до та після впливу, доцільно визначати за допомогою таких методів оцінки, як [3, с. 23-24]: метод прямого ринкового оцінювання; методи непрямого ринкового оцінювання; метод умовного оцінювання; метод групової оцінки.

Одним 3 найбільш простих методів є метод прямого ринкового оцінювання. Проте, необхідно зауважити, що «навіть в умовах розвинутого ринку ціни на природні ресурси і об'єкти навколишнього середовища тільки частково відображають їхню 
реальну цінність. Це пояснюється тим, що існуюча ринкова система господарських відносин не може адекватно розподілити природні ресурси в напрямку найбільш ефективного їх використання, тобто дати правильну вартісну оцінку їх екстенсивної експлуатації» [4, с. 15].

Серед основних недоліків методу прямого ринкового оцінювання необхідно назвати [4-6]: відсутність цін на велику кількість екосистемних послуг; неврахування реальних суспільних витрат (наприклад, витрат, пов'язаних із запобіганням забрудненню навколишнього природного середовища) та вигод використання екосистемних послуг; суспільний характер багатьох природних ресурсів, які не можуть перебувати у приватній власності і до яких можливий відкритий і безкоштовний доступ; неврахування порушеності ринку - монополізованості, субсидованості, провалів ринку, сезонних варіацій і інших коливань цін; врахування, користувачами, в першу чергу, короткострокових наслідків експлуатації природних ресурсів тощо.

В межах України основними типами природних екосистем, що піддаються негативному впливу твердих побутових відходів $\epsilon$ такі, що повністю або частково розміщені на земній поверхні (оскільки, переважно, місцем розміщення твердих побутових відходів є земна поверхня), а саме: у групі наземних екосистем ліси та степ помірної зони; у групі прісноводних екосистем заболочені угіддя (болота, болотисті ліси). Метод прямого ринкового оцінювання дозволяє оцінити, в першу чергу, групу забезпечуючих екосистемних послуг. Так, для лісових екосистем це будуть - деревина, ягоди, гриби, дичина; для степної зони корм для худоби на природних пасовищах та мед; для заболочених угідь - ягоди, очерет, будівельні матеріали тощо. Крім оцінювання забезпечуючих екосистемних послуг, метод прямого ринкового оцінювання часто застосовують для оцінювання деяких культурних послуг. Так, для всіх зазначених екосистем метод прямого ринкового оцінювання дозволяє оцінити такі екосистемні послуги, як туризм і рекреація. 
Отже, при визначенні змін у стані екосистемних активів територіальних громад від негативного впливу твердих побутових відходів, як різниці між економічними оцінками екосистемних послуг до та після впливу, одним із найпростіших у застосуванні є метод прямого ринкового оцінювання. Проте, як будь-який інший метод оцінювання, він має ряд недоліків, в першу чергу, неврахування реальних суспільних витрат та вигод використання екосистемних послуг. Зазначене сприяє спотворенню цін на екосистемні послуги та, відповідно, потребує їх коригування.

\section{Література:}

1. Офіційний сайт Міністерства громад та територій України. Стан сфери поводження $з$ побутовими відходами в Україні за 2019 рік. URL: https://www.minregion.gov.ua/napryamki-diyalnosti/zhkh/terretory/stan-sfery-povodzhennya-z-pobutovymy-vi

2. Думнов А.Д., Рыбальский Н.Г. Макроэкономические оценки на основе экосистемного учета как важнейшая международная задача. Век глобализаиии. 2015. Вип. 2 (16). URL: https://www.socionauki.ru/journal/articles/300137

3. Соловій I. Оцінка послуг екосистем, забезпечуваних лісами України, та пропозиції щодо механізмів плати за послуги екосистем. URL: http://www.enpifleg.org/site/assets/files/2131/final_report_i_soloviy_evaluation_o f_forest_ecosystem_services_provided_by_forests_of_ukraine_and_proposals_on_pe s_mecha.pdf

4. Бережная И.В., Забродько Г.В. Анализ методологии экономической оценки рекреационных ресурсов территории. Культура народов Причерноморья. 2002. № 30. URL: http://dspace.nbuv.gov.ua/handle/12345 $6789 / 108891$

5. Бобылев С.Н., Ходжаев А.Ш. Экономика природопользования. Учебник / C.Н. Бобылев, А.Ш. Ходжаев. Москва, 2003. 567 с. URL: http://www.cawaterinfo.net/library/rus/bobylev-hojaev.pdf

6. Конюшков Д.Е. Формирование и развитие концепции экосистемных услуг: обзор зарубежных публикаций. Бюллетень Почвенного института им. В.В. Докучаева. 2015. Вип. 80. С. 26-49. URL: https://cyberleninka.ru/ article/n/formirovanie-i-razvitie-kontseptsii-ekosistemnyh-uslug-obzor-zarubezhnyhpublikatsiy 